\title{
Deliberating across Difference
}

\section{Religious Accommodation and Deliberative Democracy}

\author{
Afsoun Afsahi \\ University of Amsterdam, Amsterdam, the Netherlands \\ a.afsahi@uva.nl
}

\begin{abstract}
This paper examines two cases of deliberation on the issue of religious arbitration in Canada: first, the Sharia law debate in Ontario (deliberation in the larger public sphere); and second, a deliberation on religious arbitration in British Columbia (deliberation in a small-scale structured setting). Relying on both secondary and original data, this article demonstrates that while the Sharia law debate failed to fulfill the key functions of a deliberative engagement, the small-scale deliberation was able to achieve all three functions: participants had the chance to express their opinions; there was ample dialogue and communication evident by increased empathy, perspectivetaking ability, and knowledge gains; and finally, participants were able to come to a decision, however broad, together. Through this comparison, the article highlights key barriers to deliberation across differences and concludes with some suggestions for carrying out such engagements in the future.
\end{abstract}

\section{Keywords}

deliberative democracy - religious accommodation - religious arbitration multiculturalism

\section{Introduction}

In November 2003, Syed Mumtaz Ali, a scholar of Islamic jurisprudence and a retired lawyer, announced the establishment of the Islamic Institute of Civil Justice (IICJ), which would offer religious arbitration services based on Islamic 
legal principles and in "the form of a 'shari'ah court" in Ontario, Canada. ${ }^{1}$ This announcement was met with uproar. Many women's rights organizations joined forces to challenge this enterprise. In response, the Ontario government appointed a Commission headed by former Attorney General, Marion Boyd, to study and make recommendations regarding religious arbitration in Ontario. Boyd recommended maintaining religious arbitration, albeit with some safeguards, but in February 2006, the Arbitration Act was amended to disallow the use of religious principles in arbitration cases.

This Commission was an attempt to democratize decision making on issues of religious accommodation. While not a perfect example of the practice of deliberative democracy, the debate was instructive, innovative, and, ultimately disheartening because of the failure of its deliberative democratic elements, especially within the Commission. The larger debate in the public and the final decision demonstrate the difficulties and highlight the dangers of carrying out deliberations on contentious issues of religious accommodation.

This article argues that, when properly structured, deliberations on issues of religious diversity and accommodation can fulfill the main functions of deliberation, and in doing so, can reduce the deficit in cultural and religious dialogue. It identifies three key functions of deliberative democracy that must be fulfilled in the course of deliberation: participants should have a chance to express their opinions; there should be ample dialogue and communication evidenced by increased empathy, perspective-taking, and knowledge gain; and participants should be able to come to a decision, however broad, together.

The article examines two cases of deliberation on the issue of religious arbitration in Canada: first, the Sharia law debate in Ontario (deliberation in the larger public sphere); and second, a deliberation on religious arbitration in British Columbia (deliberation in a small-scale structured setting). Relying on both secondary and original data, the article demonstrates that whereas the Sharia law debate failed to fulfill the key functions of a deliberative engagement, the small-scaled deliberation was able to achieve all three functions. Through this comparison, the article highlights key barriers to deliberation in the Sharia debate case: polarization of preexisting opinions and biases, a general lack of information sharing between participants, and a lack of autonomy of the Commission and responsiveness by the government. It concludes with suggestions for carrying out such engagements in the future.

1 Alexandra Brown, "Constructions of Islam in the Context of Religious Arbitration: A Consideration of the 'Shari'ah Debate' in Ontario, Canada”, 30(3) Journal of Muslim Minority Affairs (2010), 343, 345 . 
Deliberative democracy is "the cooperative search of deliberating citizens for solutions to political problems."2 It is centered around the idea of engaging citizens at the level of public opinion formation by bringing them together to discuss different ideas and alternatives in a space where, ideally, the force of the better argument can prevail. ${ }^{3}$ It is, therefore, premised on the assumption that under the right conditions, people are able and willing to communicate with each other in an open manner and offer reasons and explanations for their positions-becoming more aware of their own values and interests.

Deliberative democratic theory as well as deliberative mini-publics have grown in popularity, lending themselves to the ever-growing agreement that deliberative democratic engagements are complementary and useful remedies to the deficits facing mature democracies - particularly those with diverse populations. For many, increased cross-cultural and cross-religious dialogue in liberal multicultural societies is both necessary and beneficial, and deliberative democracy is seen as one way to achieve this. ${ }^{4}$

2 Jürgen Habermas, "Political Communication in Media Society: Does Democracy Still Enjoy an Epistemic Dimension? The Impact of Normative Theory on Empirical Research", 16(4) Communication Theory (2006), 411, 413 .

3 Jürgen Habermas, Legitimation Crisis (Thomas McCarthy trans., London: Heinemann, 1976), 108.

4 The list of scholars upholding such a view is rather long (See, Magdalena Dembinska \& Françoise Montambeault, "Deliberation for Reconciliation in Divided Societies", 11(1) Journal of Public Deliberation (2015), 1; John S. Dryzek \& Patrick Dunleavy, Theories of the Democratic State (Houndmills, Basingstoke, Hampshire [England]; New York: Palgrave Macmillan, 2009), 207-225; James S. Fishkin et al., "Deliberative Polling and Public Consultation", 53(4) Parliamentary Affairs (2000), 664; Archon Fung \& Mark E. Warren, "The Participedia Project: An Introduction", 14(3) International Public Management J. (2011), 341; Archon Fung, "Survey Article: Recipes for Public Spheres: Eight Institutional Design Choices and Their Consequences", 11(3) Journal of Political Philosophy (2003), 346; Kimmo Grönlund et al., "Does Enclave Deliberation Polarize Opinions?", 37(4) Political Behavior (2015), 995-1020; Rodolfo Lewanski, "Institutionalizing Deliberative Democracy: The 'Tuscany Laboratory", 9(1) Journal of Public Deliberation (2013); Jane Mansbridge et al., "The Place of Self-Interest and the Role of Power in Deliberative Democracy", 18(1)Journal of Political Philosophy (2010), 64; Brigitte Geissel \& Kenneth Newton, Evaluating Democratic Innovations: Curing the Democratic Malaise? (Abingdon, Oxon; New York; Routledge, 2012), 3-20; Mark E. Warren \& Hilary Pearse, Designing Deliberative Democracy: The British Columbia Citizens' Assembly (Cambridge University Press, 2008), 2. It also includes scholars who see deliberative democracy as a way to resolve conflicts between majority and minority cultures and religions (Seyla Benhabib, The Claims of Culture: Equality and Diversity in the Global Era (Princeton, N.J: Princeton University Press, 2002); Monique Deveaux, "A Deliberative Approach to Conflicts of Culture", 31(6) Political Theory (2003), 780-807; Monique Deveaux, Gender and Justice in Multicultural Liberal States (Oxford University Press, 2006); Sarah Song, Justice, Gender, and the Politics of Multiculturalism 
Deliberative democratic engagements, regardless of the topic under discussion, must fulfill three functions. First, a deliberative democratic engagement must afford participants the opportunity to express their opinions and raise concerns they might have. This function corresponds to the principle of inclusivity or open participation within deliberation. ${ }^{5}$ Second, a deliberative engagement must demonstrate an exchange of views and opinions. This function corresponds not only to the principle of justification or reason-giving, ${ }^{6}$ but also to those of listening and reflection ${ }^{7}$ within deliberative democratic theory. This second function goes beyond the first in asking individuals to not only express their own views, but also to listen to those of others and ask and answer questions - in other words, to deliberate. Finally, a deliberative engagement

(Cambridge University Press, 2007); Sarah Song, "Majority Norms, Multiculturalism, and Gender Equality", 99(4) American Political Science Rev. (2005), 473; Jorge M. Valadez, "The Implications of Incommensurability for Deliberative Democracy", in David Kahane et al. (eds.), Deliberative Democracy in Practice (Vancouver, ubC Press 2010), 155-173; Jorge M. Valadez, Deliberative Democracy, Political Legitimacy and Self-Determination in Multicultural Societies (Westview Pr., 2001); John S. Dryzek, "Deliberative Democracy in Divided Societies: Alternatives to Agonism and Analgesia", 33(2) Political Theory (2005), 218-242; as well as scholars who more generally endorse the virtues of cross-cultural and inter-religious dialogue: Charles Taylor, Multiculturalism: Examining The Politics of Recognition (Amy Gutmann ed., Princeton: Princeton University Press, 1994); Bhikhu C. Parekh, Rethinking Multiculturalism: Cultural Diversity and Political Theory (Harvard University Press, 2002).

5 James Bohman, Public Deliberation: Pluralism, Complexity and Democracy (Cambridge, Mass: MIт Press, 1996); Jürgen Habermas, Between Facts and Norms: Contributions to a Discourse Theory of Law and Democracy (Cambridge, MA: MIT, 1996); Archon Fung, "Varieties of Participation in Complex Governance", 66(1) Public Administration Review (2006), 66-75; Marco R. Steenbergen et al., "Measuring Political Deliberation: A discourse Quality Index", 1(1) Comparative European Politics (2003), 21-48.

6 Bohman, supra note 5; Amy Gutmann \& Dennis Thompson, Democracy and Disagreement (Cambridge, MA: Harvard University Press, 1996); Amy Gutmann \& Dennis Thompson, Why Deliberative Democracy? (Princeton: Princeton University Press, 2004); Jürgen Habermas, The Theory of Communicative Action (Thomas McCarthy trans., Boston: Beacon press, 1984); Habermas, supra note 5; Jürgen Habermas, "Deliberative Politics", in David M. Estlund (ed.), Democracy (Malden, MA: Blackwell Publishers, 2002), 107-125.

7 S. Burkhalter et al., "A Conceptual Definition and Theoretical Model of Public Deliberation in Small Face-To-Face Groups", 12(4) Communication Theory (2002), 398-422; Vincent Jungkunz, "Deliberate Silences", 9(1) Journal of Public Deliberation (2013); Baogang He, "A Deliberative Approach to the Tibet Autonomy Issue: Promoting Mutual Trust Through Dialogue", 50(4) Asian Survey (2010), 709-734; Simone Chambers, "Rhetoric and the Public Sphere: Has Deliberative Democracy Abandoned Mass Democracy?", 37(3) Political Theory (2009), 323-350; Robert E. Goodin, "Democratic Deliberation Within", in James S. Fishkin \& Peter Laslett (eds.), Debating Deliberative Democracy (Malden, MA: Blackwell, 2003), 54-79; Jürgen Habermas, On the Pragmatics of Social Interaction: Preliminary Studies in the Theory of Communicative Action (Barbara Fultner (trans.), MIT Press, 1984); Habermas, supra note 5. 
should demonstrate the completion of a task or arrival at a decision. ${ }^{8}$ The decision need not be consensual, as some suggest. ${ }^{9}$ It can simply mean making progress on a task or arriving at a non-binding or provisional agreement. ${ }^{10}$

A deliberative engagement that fulfills these three functions will likely meet the desired goals associated with deliberation. It should leave participants feeling that they have had the opportunity to talk and be heard. Participants should leave deliberation believing that they have engaged in a worthwhile process that has left them more knowledgeable and empathetic. Indeed, deliberation should leave participants not only better informed and knowledgeable about the topic under deliberation but also more socially aware. As a result of deliberation, participants should feel more confident about their capacity to engage in political discussions.

\section{Deliberating across Difference}

Is deliberation able to fulfill these functions when the topic concerns religious diversity and accommodation? Some scholars think that the contentious nature of such deliberations can derail the process and weaken the ability of deliberation to fulfill these three functions. ${ }^{11}$

8 Michael X. Delli Carpini et al., "Public Deliberation, Discursive Participation, and Citizen Engagement: A Review of the Empirical Literature", 7 Annual Review of Political Science (2004), 315-344; John Gastil, Political Communication and Deliberation (Sage, 2008); Robert E. Goodin \& John S. Dryzek, "Deliberative Impacts: The Macro-Political Uptake of Mini-Publics", 34(2) Politics \& Society (2006), 219-244; Gutmann \& Thompson, supra note 6.

9 Joshua Cohen, "Deliberation and Democratic Legitimacy", in David M. Estlund (ed.), Democracy (Malden, MA: Blackwell Publishers, 2002), 87.

10 Jane Mansbridge et al., "Norms of Deliberation: An Inductive Study", 2(1) Journal of Public Deliberation (2006).

11 For some scholars, the contentious nature of such deliberations is one factor among many that can make deliberation vulnerable (Bohman, supra note 5; Archon Fung, "Deliberation Before the Revolution Toward an Ethics of Deliberative Democracy in an Unjust World", 33(3) Political Theory (2005), 397-419; Mark E. Warren, "Institutionalizing Deliberative Democracy", in Shawn W. Rosenberg (ed.), Deliberation, Participation and Democracy (Basingstoke: Palgrave Macmillan, 2007), 272-288). Others raise more specific concerns: diversity in the values of individuals may undermine the shared identity, reduce the trust needed for deliberation (David Miller, On Nationality (New York: Clarendon Press, 1995)), and lead to a desire to shun deliberation as a way to avoid conflict (William P. Eveland \& Myiah Hutchens Hively, "Political Discussion Frequency, network Size, and 'Heterogeneity' of Discussion as Predictors of Political Knowledge and Participation", 59(2) Journal of Communication (2009), 205-224; John R. Hibbing \& Elizabeth TheissMorse, Stealth Democracy: Americans' Beliefs About How Government Should Work (Cambridge University Press, 2002); Robert Huckfeldt \& John Sprague, Citizens, Politics 
In the following sections, I look at two cases involving the topic of religious arbitration. The first case concerns the Sharia law debate in Ontario, from late 2003 to early 2006, on whether the province should continue to permit the resolution of some cases through religious arbitration. This case--the debate and the Commission--is analyzed as a public deliberation based on secondary sources. The debate, similar to the Consultation Commission on Accommodation Practices Related to Cultural Differences, carried out by Charles Taylor and Gérard Bouchard, exemplifies the difficulty of conducting public debates over issues of cultural and religious accommodation. ${ }^{12}$ What makes the Sharia law debate a particularly good case to examine is that it took place against the backdrop of support for multiculturalism in a highly diverse province in Canada. This sets it apart from the debate and dialogue around the Bouchard-Taylor Commission in Québec, which has had a longer and more contentious history with multiculturalism. ${ }^{13}$

The analysis that as a semi-deliberative process, the Sharia law debate failed to fulfill any of the functions associated with deliberative democracy because of several potent barriers. First, the polarization and salience of preexisting opinions and biases in a post-9/11 world made one of the parties in the debate particularly vulnerable. This vulnerability was translated into inequality between participants and a lack of representativeness in the coverage of the views of the different sides of the debate. Second, the debate suffered from a free-for-all approach of the media interested in its most sensational aspects.

and Social Communication: Information and Influence in an Election Campaign (Cambridge University Press, 1995); Diana C. Mutz \& Paul S. Martin, "Facilitating Communication Across Lines of Political Difference: The Role of Mass Media", 95(1) American Political Science Rev. (2001), 97; Elizabeth Theiss-Morse \& John R. Hibbing, "Citizenship and Civic Engagement”, 8(1) Annual Review of Political Science (2005), 227-249). Such diversity between individuals could mean different deliberative styles and communicative approaches (John S. Dryzek et al., "Toward a Deliberative global Citizens' Assembly", 2(1) Global Policy (2011), 33-42; Karen Umemoto \& Hiroki Igarashi, "Deliberative Planning in a Multicultural Milieu", 29(1) Journal of Planning Education and Research (2009), 39-53), not to mention irreconcilable values and opinions (John Forester, Dealing With Differences: Dramas of Mediating Public Disputes (Oxford University Press, 2009); Jungkunz, supra note 7), which can also complicate the process of deliberation.

12 See the report by Bouchard and Taylor for more information (Gérard Bouchard \& Charles Taylor, “Building The Future: A Time for Reconciliation", in Québec: Gouvernement du Québec (2008)).

13 Guy Rocher, "Les Ambiguïtés d'un Canada bilingue et biculturel": Le Québec en mutation, (Montreal: Hurtubise HM H, 1973); Julien Harvey, Une Impasse, Le Multiculturalism? Conférence fédérale-provinciale sur le multiculturalisme (Winnipeg, 1985); Micheline Labelle, "Immigration, Culture et Question Nationale", 14 Cahiers de Recherche Sociologique (1990), 143-151. 
The parties remained uninformed or misinformed about significant aspects of each other's views and opinions. Finally, the most deliberative or consultative element of the debate, the Commission led by Boyd, was never fully autonomous. Politicians were not involved in the process and they were not bound by the decisions of the Commission. The lack of accountability and responsiveness to the consultation process further undermined the deliberation.

The second case concerns a one-day deliberation between 40 participants in Vancouver, BC on whether or not the British Columbia government should allow for the resolution of some cases in arbitration processes that rely on religious law. This deliberative engagement, which was carried out as part of a larger project looking at best methods and practices of facilitating contentious issues, is analyzed through mostly quantitative data collected using pre- and post-deliberation questionnaires. This analysis serves only as proof of concept that deliberative processes over contentious issues of religious accommodation are not necessarily doomed to fail.

\subsection{Sharia Law Debate in Ontario}

From 1991 to 2003, Christian, Jewish, and Muslim residents in Ontario used the Arbitration Act of 1991 "to arbitrate private disputes according to religious laws with little public debate."14 There are two reasons for the relative inconspicuousness of the instances of religious arbitration. First, they were not highly prevalent. Second, "those religious groups who did engage in faith-based arbitration were not subject to the sort of intense public scrutiny as Muslims [were] in the post $9 / 11$ political environment."15

As noted above, however, this relative inconspicuousness changed in late November 2003, with Syed Mumtaz Ali's announcement that the Islamic Institute of Civil Justice's jurisdiction was to be limited to "family law and inheritance disputes within the Muslim community in Canada."16 This announcement was met with uproar, the mobilization of women's rights organizations, ${ }^{17}$ and culminated in the establishment of a Commission led by former Attorney General Marion Boyd to study the issue and make recommendations. As part of

\footnotetext{
14 Brown, supra note 1 , at 344.

15 Daniel Munro, "Faith, Democracy, and Deliberative Citizenship: Should Deliberative Democrats Support Faith-Based Arbitration?", 10(1) Contemporary Political Theory (2011), $102,105$.

16 Sherene H. Razack, "The 'Sharia Law Debate' in Ontario: The Modernity/Premodernity Distinction in Legal Efforts to Protect Women from Culture", 15(1) Feminist Legal Studies (2007), $3,8$.

17 These organizations included the Women's Legal Education and Action Fund (L.E.A.F.), the National Association of Women and the Law (N.A.W.L.), the Metropolitan Toronto Action Committee on Violence Against Women (M.E.T.R.A.C.), and the National Council of University Women.
} 
the investigation, "Boyd met with over 50 individuals and organizations from July to September 2004,"18 and "recommended the continued use of religious arbitration in the province, while suggesting a series of safeguards."19 Despite Boyd's recommendation, the government of Dalton McGuinty revised the Ontario Arbitration Act 1991 to ban the use of religious principles in arbitration processes. $^{20}$

\subsection{Analysis}

Did the Sharia law debate, as a public deliberation of sorts, deliver on the key functions of deliberative democracy? Did all affected and interested parties have a chance to express their opinions? Did participants engage in a dialogue by hearing each other out and responding to one another? Were the parties able to reach a decision, however non-binding? The analysis in this section demonstrates that none of these functions were fulfilled.

\subsubsection{Function 1-Chance to Express One's Views and Opinions}

An examination of the Sharia law debate demonstrates that many voices, particularly those of Muslim women, which should have been prominent, were left out of the debate. When these voices were included, they were often disregarded and disrespected, as the misguided views of individuals under the domination of Islam.

The debate obfuscated the complexity of faith-based arbitration (FBA), Islam, and individuals' reasons for partaking in FBA. In a post-9/11 world, the debate quickly came to be focused on Muslim immigrants and their desire to use FBA, without connecting this desire to that of the Christian and Jewish members of society who had also been using FBA. ${ }^{21}$ Yet, even in the overemphasis on Islam, the debate failed to capture the intricacies and the subtle, yet

18 Razak, supra note 16 , at 9.

19 Brown, supra note 1, at 343.

20 Anna Korteweg summarized these safeguards as "[focusing] institutionalized oversight and education on the principles of religious arbitration and Canadian family law. Courts were directed to look at arbitral decisions in the aggregate to identify whether rulings contravened existing Canadian law" (Anna C. Korteweg, "The Sharia Debate in Ontario: Gender, Islam, and Representations of Muslim Women's Agency", 22(44) Gender \& Society (2008), 434, 436). (See also Audrey Macklin, "Multiculturalism Meets Privatisation: The Case of Faith-Based Arbitration", 9(3) International Journal of Law in Context (2013), 343, 363; Munro, supra note 15 , at 177-178 for more detailed account of the safeguards).

21 Brown, supra note 1, at 343-356; Canadian Press Staff. "Ontario Passes Bill Prohibiting Religious Arbitration”. 2006. The Globe and Mail, Retrieved 31 Dec. 2019, theglobeandmail.com/news/national/ontario-passes-bill-prohibiting-religious-arbitration/article 18155643. In Boyd's defense, her Report discusses the Jewish and Christian FBA, but the criticism raised by Brown is more specific. According to Brown, "the report employs discourse about immigrants to Canada exclusively in discussion of Muslim religious 
crucial, differences within Islam, including, for example, the variations in the "different schools of Islamic jurisprudence."22

The debate also largely ignored the views of women who wanted to maintain the possibility of FBA and the often-compelling reasons they had for preferring and choosing to adjudicate their personal matters under a different law than that of Canada. The "[f] eminist rejection of faith-based arbitration left no room to stand for women seeking to live a faith-based life." ${ }^{23}$ Therefore, the debate failed to acknowledge the "spiritual component inherent in family dispute resolution" 24 and the "religious convictions" of Muslim women who desired "religious sanction for ending [a] marriage which they viewed as sacred." 25 This is particularly problematic because the underlying force behind the opposition to FBA in Ontario was the desire to protect women who would otherwise be ignored, disrespected, and exploited by their religion.

In addition to the theological arguments in support of $\mathrm{FBA}$, the debate was largely devoid of a discussion of the "non-theological arguments advanced by some pro-FBA groups." 26 The fact that "FBA saves taxpayers' money"27 was not a centerpiece of the debate. Neither were the beliefs of many "Ontarian Muslims [who felt] that their interests and confidentiality [were] better protected by an imam, who also typically does not charge for his services, unlike a professional counselor, mediator or lawyer." 28 The debate also made no mention of the fact that "a Muslim woman [could suffer] an economic loss under Ontario family law" which "may require [her] to give away a half share of her wealth, perhaps also including the mahr (the dowry given her by the husband) that Islamic law secures her." 29

arbitration and not in connection with Christian or Jewish cases, although all three forms of religious arbitration are relevant to the report" (Brown, supra note 1, at 348).

22 Korteweg, supra note 20.

23 Razak, supra note 16, at 13.

24 Uzma Ashraf quoted in Tabassum Fahim Ruby, “The Question of Muslim Women's Rights and the Ontario Shari'ah Tribunals: Examining Liberal Claims", 34(2) Frontiers: A Journal of Women Studies (2013), 134, 140.

25 Ruby, supra note 24.

26 Jennifer A. Selby, "Promoting the Everyday: Pro-Sharia Advocacy and Public Relations in Ontario, Canada's 'Sharia Debate', 4(3) Religions (2013), 425-426. Selby expressed admiration for former attorney general Marion Boyd, who included such positions in her report. Yet, "these positions did not translate into public discourse" (ibid., at 426).

27 Selby, supra note 26 , at 431.

28 Ibid., at 431.

29 Ruby, supra note 24, at 141. The debate did not take into account that "according to Islamic law a woman would have no legal obligation to contribute to child support, which would be solely the father's responsibility" (Ruby, supra note 24, at 141). Ruby, much like Selby, was quick to note that these factors were included in the report by Marion Boyd. 
Power and status inequalities between parties in a post-9/11 world meant that the Sharia law debate in Ontario was dominated by a few groups that often deliberately failed to include the voices of others, thus expressing and highlighting limited perspectives. The most represented and repeated narrative portrayed Muslim women as vulnerable, childlike, and in need of protection, and framed the fight against $\mathrm{FBA}$ as one resisting the oppression of women by their religious beliefs. ${ }^{30}$

Muslim women were presented as being unable "to act in their own selfinterest given the pressures of their family and community and given existing experiences with the treatment of women within informal Islamic jurisprudential practice."31 Patriarchy was presented as a characteristic of Islam, and autonomy was framed as resistance to it. ${ }^{32}$ Consider this example:

At a public meeting sponsored by Arjomand and the International Campaign to End Sharia, a group of young veiled women from a Somali Youth

$30 \quad$ Korteweg, supra note 20, at 434; Eléonore Lépinard, "In the Name of Equality? The Missing Intersection in Canadian Feminists' Legal Mobilization Against Multiculturalism", 53(12) American Behavioral Scientist (2010), 1763-1787; Selby, supra note 26, at 425. Each of these authors highlighted a different group or discourse that dominated the debate. In her research, Korteweg singled out the "secular Muslim voices arguing against" FBA and the "members of majority society" as those whose voices drowned those of others in the debate. Lépinard, for her part, also focused on the majority society, in particular various institutions in civil society. Looking at the National Association of Women and the Law (NAWL), which was the main actor in shaping the Sharia law debate, Lépinard pointed out that NAWL did not solicit or receive any "direct or indirect testimony of discriminatory arbitral decisions against women" to assess and make a decision regarding FBA. Instead, "NAWL relied on its previous expertise and its many experiences with respect to women and the law." The only difference was that "the figure of the vulnerable woman changed, from woman victim of domestic violence to vulnerable Muslim/immigrant woman" (Lépinard, ibid., at 1775). Selby focused on the other side of the debate and the fact that "a non-mainstream Islamically-conservative position dominated the debate" (Selby, supra note 26 , at 425). Several explanations are possible for this domination and the disregard for the mainstream Islamic positions. The first had to do with the lack of knowledge regarding "the parameters of the traditions of Islamic law" by the main audience of the Sharia law debate. This lack of knowledge meant that few questioned or challenged the "more extremist positions like the IICJ's." Putting "together a counter-narrative" was also complicated by "the tremendous ethnic and legal diversity among the Ontario Muslim community" (Selby, supra note 26 , at 426 ). Finally, it was the simplicity of the "extremist views" that allowed them to be "more readily taken up by opponents and through media statements" (427). The alternative would have required the media and the opponents of FBA to pay attention to and allow the expression of views by diverse groups of Muslims who preferred FBA for a variety of nuanced and often unconnected reasons.

31 Korteweg, supra note 20, at 447.

32 Ruby, supra note 24, at 141; Korteweg, supra note 20, at 434. 
group... argued that Sharia would be more applicable in their lives should they choose to use it for family issues. Most of their remarks were dismissed by the speakers on the platform on the basis that the young women did not know how fundamentalism operated. Dismissed as naive, and told that they had been coerced into wearing the veil, some of the young women chose to leave the meeting. ${ }^{33}$

This example epitomizes how opinions and biases regarding Islam created the conditions that systematically left out, ignored, or dismissed views of those who needed to express them.

\subsubsection{Function 2-Meaningful Dialogue and Communication}

A similar pattern can be seen when examining whether meaningful dialogue took place in the course of the Sharia law debate. This examination paints a rather dark picture of the quality of communication and deliberation between different parties in the debate. Consider the following examples.

First, the debate was distinguished by several continuous mischaracterizations and misconceptions, which did not diminish or disappear as a result of the information sharing that took (or should have taken) place during the debate. One of these mischaracterizations had to do with the tendency of the debate, and even of the report by Marion Boyd, to "collapse Muslim and immigrant identity." ${ }^{34}$ In both the debate and the report, "Muslim women [were presented] as new immigrants to Canada who are unaware of their legal rights, isolated in a patriarchal immigrant community, and perhaps unable to speak English." ${ }^{35}$ Although this is true for some Muslim women, it is not true for all of them. Similarly, an immigrant woman may fit all these descriptive characteristics and not be Muslim. Finally, FBA did not exclusively affect Muslim women, and the undue emphasis on the effect of Sharia law on Muslim women from immigrant communities, which started the debate, never changed in the three years. This demonstrates the absence of a dialogue and communication between participants with differing perspectives.

The second notable and continuous mischaracterization had to do with the "[repeated invocation of] 'one law for all' as a slogan directed against alternative normative frameworks based on religion." ${ }^{36}$ The opponents of FBA insisted on portraying it "as a demand for a separate and parallel regime," but ignored

\footnotetext{
33 Razak, supra note 16 , at 4-13.

34 Brown, supra note 1 , at 349 .

35 Brown, supra note 1 , at 350.

36 Macklin, supra note 20 , at 363 .
} 
the fact that "the state's existing regulatory regime of family law already invited and encouraged parties to resolve their family matters outside the courthouse."37 FBA, far from being a parallel system, was simply "a variant of private ordering already authorised within the existing architecture of family law." 38 This may not appear to be an important distinction in the grand scheme of the debate, but it is paradigmatic of the lack of meaningful dialogue. In framing support for FBA as an alternative to Canadian law, as opposed to a system authorized by it, the opponents were able to present the supporters of $\mathrm{FBA}$ as desiring to live outside of Canadian law, thereby claiming greater legitimacy and legality for their own side. The fact that FBA did not constitute a separate system outside of Canadian law and unsanctioned by it was mentioned not only its proponents but also by legal scholars and officials. The continued mischaracterization of FBA demonstrates the failure to communicate and learn from public deliberation.

Finally, despite research showing that individuals sought the advice of imams primarily for mediation rather than "legally-binding arbitration,"39 the "spectre of stoning women and capital punishment" remained present. Similarly, although the same research showed that most instances of such mediation took place in the "imams' offices or in family homes and not in courtroom settings," the use of the fear-inducing term "Sharia courts," sensationalized by the media, remained unchanged despite evidence and testimony to the contrary. ${ }^{40}$ In itself, this mischaracterization may not seem problematic, but the continuation of false statements, particularly equating arbitration in civil matters with courts in charge of criminal law, is problematic. Admittedly, the only way to be sure that participants have been engaging in a meaningful dialogue by listening and reflecting on what was said is to interview the parties involved, but the failure to make one's position more accurate indicates a lack of knowledge acquisition, and by extension, failed dialogue.

The debate also demonstrated the participants' propensity to talk over, rather than with, one another. For instance, although both sides of the debate resorted to the principles of equality and multiculturalism codified in the Canadian Charter of Rights and Freedoms as the main framework, "each actor interpreted the Charter and Ontarian law according to its previous legal analysis." ${ }^{41}$ According to Avigail Eisenberg, the framework of multiculturalism was hijacked by both sides. Instead of focusing on the justice and fairness of

37 Macklin, supra note 20, at 347.

38 Macklin, supra note 20, at 344.

39 Macfarlane in Selby, supra note 26 , at 425.

40 Ibid, at 425 .

41 Lépinard, supra note 31, at 1780. 
the claims made by the two sides, the debate became a disagreement over "what kind of multiculturalists are we?"42 On the side of women, multiculturalists argued that Canadian multiculturalism was still "liberal in inspiration" and hence could not "accommodate practices that weakened the status and equal rights of women." 43 In particular, they "argued that, if allowed to guide decision-making, sharia law would result in violations of the Canadian Charter of Rights and Freedoms' section 7 'liberty', and especially section 15 'equality' rights." 44 On the side of culture, multiculturalists argued that the "principles of multiculturalism" ensured the protection of cultures and provided them with rights to ensure their practice and their preservation. ${ }^{45}$ They not only dismissed the concerns about possible violations of sections 7 and 15 of the Charter ${ }^{46}$ but also "offered a Charter argument of their own, noting that section 27 requires that the Charter 'be interpreted in a manner consistent with the preservation and enhancement of the multicultural heritage of Canadians." ${ }^{47} \mathrm{Al}-$ though both parties appear to have appealed to the Charter to engage on the shared terrain of constitutional law and debate on terms that each side could accept, this is not the case. Both sides were engaging in a reductionist, rather than holistic, interpretation of the Charter. By cherry-picking only one section of the Charter while ignoring the others, both sides were at fault and failed to respond to the concerns of the other side.

Perhaps one of the main reasons behind the failure of the Sharia law debate to foster genuine dialogue and communication between the parties can be blamed on the media and their approach to the coverage of the issue. ${ }^{48}$ Most

Avigail Eisenberg, "Identity, Multiculturalism, and Religious Arbitration: The Debate Over Shari'a Law in Canada", in Sexual Justice/Cultural Justice (London: Routledge, 2007), 211, 214.

43 Eisenberg, supra note 43, at 214.

44 Munro, supra note 15, at 106.

45 Eisenberg, supra note 43, at 214.

46 Section 7 concerns "Life, liberty and security of person" whereas Section 15 guarantees "Equality before and under law and equal protection and benefit of law."

47 Munro, supra note 15, at 106.

48 Deliberative democratic theorists who focused on the quality of deliberation in the public sphere have long discussed the importance of media in ensuring the possibility of high-quality and impactful public deliberation (Simon Niemeyer, "The Emancipatory Effect of Deliberation: Empirical Lessons from Mini-Publics", 39(1) Politics \& Society (2011), 103-140; Dembinska \& Montambeault, supra note 4; Fung, supra note 11; R. S. Ratner, "Communicative Rationality in the Citizens' Assembly and Referendum Process", in Mark E. Warren \& Hilary Pearse (eds.) Designing Deliberative Democracy: The British Columbia Citizens' Assembly (Cambridge: Cambridge University Press, 2008), 145-165; Bruce Ackerman, "Reviving Democratic Citizenship?", 41(2) Politics \& Society (2013), 309-317; John Gastil \& Robert Richards, "Making Direct Democracy Deliberative Through Random 
scholars who have written about the Sharia law debate used similar language to describe the media reaction to the Sharia law debate: "media frenzy," 49 "media orchestrated [panic]," "a spectacle,"50 "media hysteria," and "sensationalist media headlines." ${ }^{51}$ The particular approach that the media took in covering the Sharia law debate can be criticized on at least three grounds. First, it often "involved misunderstandings and misconceptions about the scope and nature of religious arbitration."52 This stemmed from the fact that "media's interest [was aroused] only when it became public that Islam practiced [FBA]."53 Therefore, the "proposed tribunals were quickly dubbed 'Shari'a courts' in the media," ignoring individuals from other faiths who practiced FBA. ${ }^{54}$ Second, the panic orchestrated by the media "played a significant role in colouring the attitudes of many Canadians regarding the presence of faith-based arbitration, and may have, in fact, influenced, the government's decision to ban the practice." 55 Finally, the diversity and nuance in the different positions on FBA "were not captured by the public debate for... not being sensational enough for the media, who preferred a simplistic, reductive approach to the issues at hand." 56

\subsubsection{Function 3- Decision Making}

Was the Sharia law debate able to fulfill on the democratic function of deliberation by ensuring the ability of all those affected to contribute to the decisionmaking process?

Procedurally, the decision by Premier Dalton McGuinty to change the Arbitration Act so as to discontinue the use of religious law in arbitration cases was democratic. Substantively, however, his decision was in direct contradiction with the recommendation by Marion Boyd. This is particularly problematic because the Boyd Report, despite its many failings and shortcomings, was the product of the most inclusive, transparent, and deliberative aspect of the debate. As Brown noted, "Marion Boyd began her review in the summer of 2004,

Assemblies", 41(2) Politics \& Society (2013), 253-281; Jürgen Habermas, The Structural Transformation of the Public Sphere: An Inquiry Into a Category of Bourgeois Society (Thomas McCarthy (trans.), MIT press, 1991)).

49 Brown, supra note 1 , at 345 .

$50 \quad$ Razak, supra note 16 , at $7,27$.

51 Maryam F. Razavy, Faith-Based Arbitration in Canada: The Ontario Sharia Debates (2010) (Ph.D. dissertation, University of Alberta, ProQuest Dissertations Publishing), 246, 251.

52 Brown, supra note 1 , at 345 .

53 Lépinard, supra note 31 , at 1779.

54 Macklin, supra note 20, at 346.

55 Razavy, supra note 5 , at 246.

56 Selby, supra note 26 , at 433 . 
opening the call to Ontarians to provide their thoughts and opinions on arbitration and the possible effects on vulnerable people." 57 By rejecting the Report, which included more or less diverse views on the issue of $\mathrm{FBA}$, the Ontario government effectively ended the debate and silenced the voices reflected in the Report. This is not to say that only an acceptance of the Report would have fulfilled its democratic function. The crucial point is that the decision of the government to end the debate and discontinue FBA in Ontario was the exact opposite of the recommendation emerging from a process commissioned by the same government, which sought to hear from Ontarians regarding their views and concerns about arbitration. In many ways, the Report, with the safeguards recommended for the protection of women, represented a fair deliberative compromise. The decision not only went against the most democratic aspect of the debate but also ended the continued debate by citizens.

The decision also demonstrated key shortcomings of the process. First, key stakeholders - in this case, the people's elected representatives-did not participate in the Commission or the larger deliberation. This left out important interests that, without being discussed and open to scrutiny, affected the final decision. Second, the final arbiters were not bound by the decisions of the Commission. The Commission had no way of holding decision makers accountable for a decision that went fully against its recommendations. Although during the consultative process the Commission maintained its autonomy, it did not have the capacity to put its decision into effect.

Substantively, nearly all scholars agree that the decision of the government was bad for all sides of the debate. ${ }^{58}$ Although it "[denied] legal recognition to faith-based arbitration," it did not go as far as "[preventing] parties from engaging mediators (as opposed to arbitrators)" or "negotiating agreements according to advice from religious authorities about the requirements of religious law."59 In both cases, "[religion] can inform... [the decision and] rulings so long as the texts of final rulings use the language of Canadian law and make no reference to religious principles." 60 This meant that the main concern of the opponents of FBA remained even after the decision by the Ontario government: "women [remained] unprotected."61 "[Unregulated] or 'back alley'

57 Brown, supra note 1 , at 345 .

$5^{8}$ One of the exceptions is Eléonore Lépinard who saw the legal changes made by the McGuinty as “a success for the 'No Religious Arbitration' coalition” (Lépinard, supra note 31, at 1765$)$.

59 Macklin, supra note 20, at 350.

6o Selby, supra note 26 , at 429 .

61 Razak, supra note 16 , at 29. 
arbitration,"62 which is "without the oversight of Canadian legal institutions,"63 meant that individuals were left with "little to no access to a legal and political system... [protecting] their rights," 64 and leaving open the "clear possibility of abuse." 65 In the end, the decision did not ban FBAs, and the images and discourse surrounding Muslims and multiculturalism in Canada were overly negative and damaging. ${ }^{66}$

In short, as an example of a public deliberation, the Sharia law debate censored and silenced voices; failed to increase knowledge, empathy, and perspective-taking; and failed both procedurally and substantively to bring about a deliberatively-reached democratic decision. The Sharia law debate might lead us to conclude that deliberations over contentious religious issues are doomed to fail. The debate also highlights the pitfalls of such debates, which, if acknowledged, can be remedied: polarization of preexisting biases and opinions, inequality between participants, failure of the media to inform parties, and the lack of autonomy of the deliberation.

\subsection{Deliberation on Religious Arbitration in British Columbia}

In this section, I examine whether a small-scale deliberation on whether to permit religious arbitration in British Columbia was able to fulfill the three functions identified earlier. This deliberation took place in November 2015 and was part of a larger study examining the dynamics and facilitation of deliberations under conditions of cultural and religious diversity.

\subsubsection{Data and Method}

The data were collected through three deliberative engagements involving 40 students at a public research university in Canada. The study was approved by the Behavioural Research Ethics Board of the university before the recruitment of the participants. The students were randomly divided and assigned to three groups for three different sessions of deliberation on three separate days, from 10:00-14:30. ${ }^{67}$ The appendix includes further information about the recruitment process and the background of the participants. A week before each deliberation, participants were sent an information pamphlet on religious arbitration, a timetable for each day, and rules of deliberation. All the sessions

\footnotetext{
62 Munro, supra note 15 , at 104.

63 Korteweg, supra note 20, at 445.

64 Munro, supra note 15 , at 104.

65 Korteweg, supra note 20, at 445.

66 Eisenberg, supra note 43 , at 211.

67 The deliberations were held on 1.11.2015, 7.11.2015, and 8.11.2015.
} 
were moderated by trained facilitators, and pre- and post-deliberation questionnaires were distributed and completed by participants. ${ }^{68}$

\subsubsection{Results and Analysis}

For the sake of clarity, I follow a similar organizational structure as the previous section when presenting the results from the pre- and post-deliberation questionnaires. The appendix includes further descriptive statistics of the variables discussed here.

\subsubsection{Function 1 - Chance to Express One's Views and Opinions}

Did participants feel like they were given the chance to express their opinions? To examine whether deliberation fulfilled this function, I rely on two items in the post-deliberation questionnaire:

1. "I had ample opportunity in the small group discussions to express my views."

2. "The other group members respected my views on the issue we discussed." Both items were scored on a 5-point scale, ranging from -2, "Strongly disagree" to +2 , "Strongly agree." As shown in Figure 1, when participants were asked about their opportunity to express their views during the deliberation, $95 \%$ (38 out of 40 participants) agreed or strongly agreed that they had had ample opportunity to do so. Similarly, when asked whether they felt that their views were respected, $100 \%$ agreed or strongly agreed with this statement.

\subsubsection{Function 2-Meaningful Dialogue and Communication}

Was there enough dialogue between participants, as evidenced by increased empathy, perspective-taking, and knowledge gains? To examine whether the
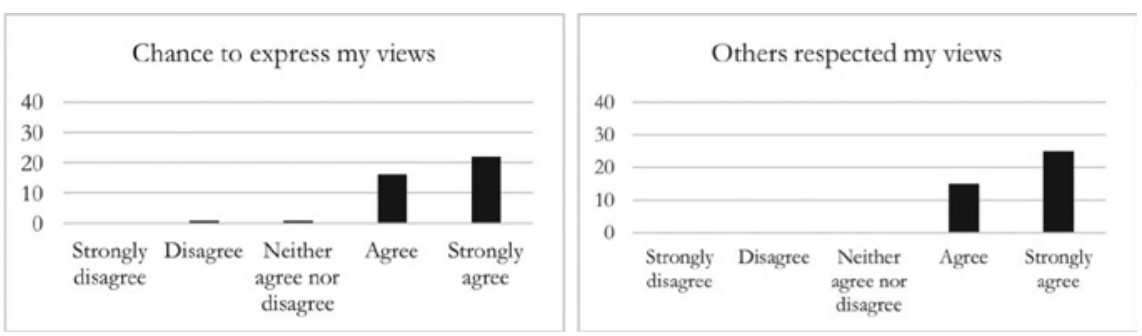

FIGURE 1 Chance to express one's views and opinions

68 Many of the questions are drawn from the survey designed by the Participedia group. For more information see, https://participedia.net. 

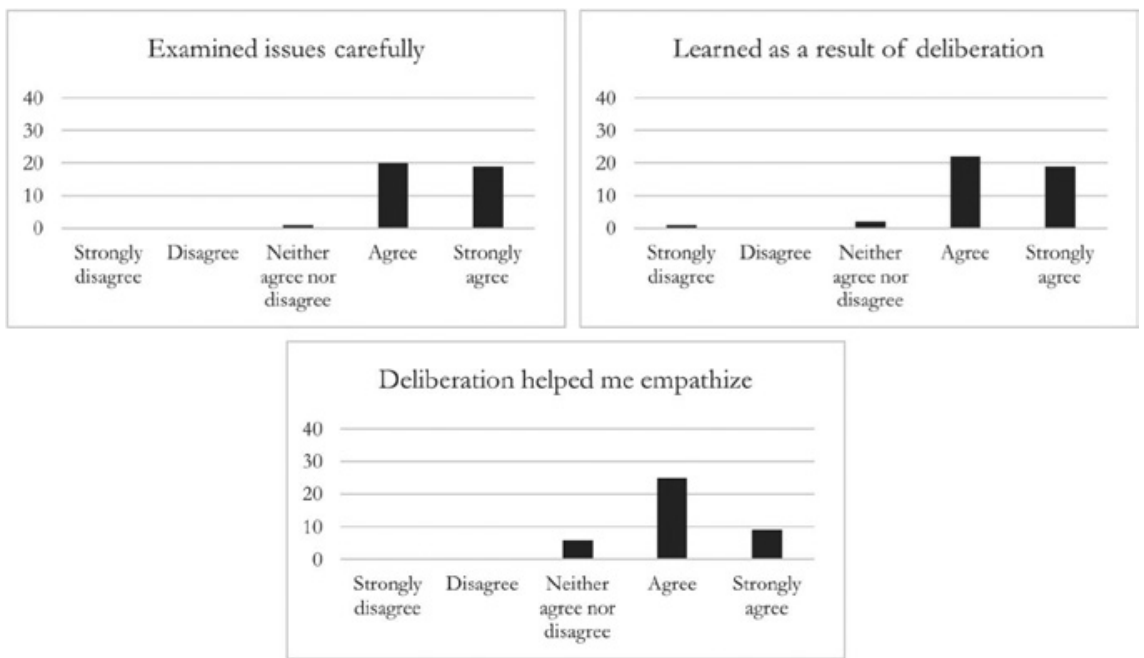

FIGURE 2 Participants' assessments of dialogue and communication in deliberation

deliberation fulfilled this function, I rely on single-point data and questions asked before and after the deliberation. Participants were asked whether, in their view:

1. "Our group carefully examined the important issues surrounding religious arbitration."

2. "I learned a lot from participating in this process."

3. " "This process helped me empathize with the challenges of others."

Responses were scored on a 5-point scale, ranging from -2, "Strongly disagree" to +2 , "Strongly agree." As shown in Figure 2, when participants were asked about their assessment of whether or not their group examined issues carefully, $98 \%$ agreed or strongly agreed that they had indeed done so. Similarly, when they were asked whether they learned as a result of deliberation, $92 \%$ agreed or strongly agreed. Finally, when asked whether the process helped them empathize more, $85 \%$ agreed or strongly agreed that the process was successful at helping them empathize with others.

Participants were asked several questions before and after the deliberation. This allowed us to examine what effect, if any, deliberation had on participants. First, participants were asked a series of questions measuring their perspective-taking ability before and after deliberation. All items were scored on a 5-point scale, ranging from -2 , "Strongly disagree" to +2 , "Strongly agree." 
TABLE 1 Summary of paired samples t-tests for knowledge, perspective-taking, and empathic concern

\begin{tabular}{|c|c|c|c|c|c|c|c|c|}
\hline \multirow{3}{*}{$\begin{array}{l}\text { Paired samples } \\
\text { (pre- and } \\
\text { post-deliberation) }\end{array}$} & \multicolumn{8}{|c|}{ Paired differences } \\
\hline & \multirow[t]{2}{*}{ Mean } & \multirow[t]{2}{*}{$\begin{array}{l}\text { Std. } \\
\text { deviation }\end{array}$} & \multirow[t]{2}{*}{$\begin{array}{l}\text { Std. error } \\
\text { mean }\end{array}$} & \multicolumn{2}{|c|}{$\begin{array}{l}95 \% \text { confidence interval } \\
\text { of the difference }\end{array}$} & \multirow[t]{2}{*}{$\mathbf{t}$} & \multirow[t]{2}{*}{ df } & \multirow{2}{*}{$\begin{array}{l}\text { P-value } \\
\text { (sig. two } \\
\text { tailed) }\end{array}$} \\
\hline & & & & Lower & Upper & & & \\
\hline Knowledge & -0.12 & 0.22 & 0.03 & -0.19 & -0.05 & -3.48 & 39 & 0.001 \\
\hline Perspective-taking & -0.31 & 0.49 & 0.08 & -0.46 & -0.15 & -3.96 & 39 & 0.0003 \\
\hline Empathic concern & -0.12 & 0.34 & 0.05 & -0.22 & -0.005 & -2.11 & 39 & 0.04 \\
\hline
\end{tabular}

The measures were then merged into a single variable. ${ }^{69}$ There was mean increase of 0.31 points in perspective-taking ability as a result of the deliberation ( 0.575 to 0.88 ). This change is statistically significant ( $\mathrm{p}=0.0003$ ). Second, participants were asked a series of questions measuring their empathic concern before and after deliberation. All items were scored on a 5-point scale, ranging from -2 , "Strongly disagree" to +2 , "Strongly agree." The measures were merged into a single variable ${ }^{70}$ showing a mean increase 0.12 points in empathic concern as a result of the deliberation ( 0.835 to 0.95). This change is (borderline) statistically significant $(\mathrm{p}=\mathbf{0 . 0 4})$. Finally, participants were asked a series of questions measuring their knowledge about the issue of religious arbitration before and after the deliberation. ${ }^{71}$ Possible responses were "True," "False," and "I don't know." There was 0.12 points mean increase in knowledge as a result of the deliberation ( 0.53 to 0.65$)$. The change is statistically significant $(\mathrm{p}=0.001)$. Results are summarized in Table 1.

\subsubsection{Function 3 - Decision Making}

Did participants make a decision together? Did they, as a result of the deliberation and making a decision together, feel more politically efficacious and

69 The questions were adopted from the Interpersonal Reactivity Index (Mark H. Davis, "Measuring Individual Differences in Empathy: Evidence for a Multidimensional Approach", 44(1) Journal of Personality and Social Psychology (1983), 113-126). See appendix for specific items.

70 The questions were adopted from the Interpersonal Reactivity Index (Davis, supra note 70). See appendix for specific items.

71 The appendix includes a list of these questions. 


\begin{tabular}{|c|c|c|c|}
\hline $\begin{array}{l}\text { Table } \\
\text { number }\end{array}$ & $\begin{array}{l}\text { Decision: } \\
\text { Yes/No }\end{array}$ & $\begin{array}{l}\text { Substance of the } \\
\text { decision }\end{array}$ & Comments \\
\hline 1 & Yes & Allow arbitration & $\begin{array}{l}\text { Only if safeguards for protection of } \\
\text { women/children are included }\end{array}$ \\
\hline 2 & Yes & Allow arbitration & $\begin{array}{l}\text { Allowed to study decisions and } \\
\text { outcomes; open to revision in the } \\
\text { future }\end{array}$ \\
\hline 3 & No & $\mathrm{N} / \mathrm{A}$ & Ran out of time \\
\hline 4 & Yes & Allow arbitration & $\begin{array}{l}\text { Only if safeguards for protection of } \\
\text { women/children are included }\end{array}$ \\
\hline 5 & Yes & Allow arbitration & $\begin{array}{l}\text { Only if safeguards for protection of } \\
\text { women/children are included; } \\
\text { open to revision in the future }\end{array}$ \\
\hline 6 & Yes & $\begin{array}{l}\text { Disallow } \\
\text { arbitration }\end{array}$ & $\begin{array}{l}\text { Open to revision in the future if } \\
\text { need arises }\end{array}$ \\
\hline 7 & Yes & Allow arbitration & $\begin{array}{l}\text { Only if safeguards for protection of } \\
\text { women/children are included; } \\
\text { open to revision in the future }\end{array}$ \\
\hline 8 & Yes & $\begin{array}{l}\text { Disallow } \\
\text { arbitration }\end{array}$ & $\mathrm{N} / \mathrm{A}$ \\
\hline
\end{tabular}

confident about their own abilities to make decisions with others? As shown in Table 2, seven out of eight groups were able to reach some sort of a decision by the end of the day. In some cases (Tables 2, 5, 6, and 7), participants did not reach a substantive decision for or against arbitration with which all could agree. In these cases, participants retained the option of revising their decision in the future, which may be regarded as a form of fair compromise.

Participants in the deliberation were asked two questions before and after deliberation regarding their political efficacy and decision-making ability:

1. "I believe that through the conversation that we have/had today, we will be/were able to make a decision together."

2. "Sometimes politics and government seem so complicated that a person like me can't really understand what's going on."

The first measure is specific to the deliberation: did the participants' view on their ability to make a decision together increase as a result of the process? The 
TABLE 3 Summary of paired samples t-tests for decision-making ability and political efficacy

\begin{tabular}{|c|c|c|c|c|c|c|c|c|}
\hline \multirow{3}{*}{$\begin{array}{l}\text { Paired samples (pre- } \\
\text { and post-deliberation) }\end{array}$} & \multicolumn{8}{|c|}{ Paired differences } \\
\hline & \multirow[t]{2}{*}{ Mean } & \multirow{2}{*}{$\begin{array}{l}\text { Std. } \\
\text { deviation }\end{array}$} & \multirow{2}{*}{$\begin{array}{l}\text { Std. } \\
\text { error } \\
\text { mean }\end{array}$} & \multicolumn{2}{|c|}{$\begin{array}{l}95 \% \text { confidence interval } \\
\text { of the difference }\end{array}$} & \multirow[t]{2}{*}{1} & \multirow[t]{2}{*}{ df } & \multirow{2}{*}{$\begin{array}{l}\text { P-value } \\
\text { (sig. two } \\
\text { tailed) }\end{array}$} \\
\hline & & & & Lower & Upper & & & \\
\hline Decision-making ability & -0.4 & 0.9 & 0.14 & -0.69 & -0.11 & -2.8 & 39 & 0.008 \\
\hline Political efficacy & -0.3 & 0.72 & 0.11 & -0.53 & -0.07 & -2.62 & 39 & 0.01 \\
\hline
\end{tabular}

second measure concerns general political efficacy. One of the goals associated with deliberation is increased political efficacy and confidence in one's abilities to engage in similar processes in particular, and in politics in general: did participants become more politically efficacious as a result of deliberation?

There was a mean increase of 0.4 points in decision-making ability as a result of deliberation ( 0.6 to 1 ). This change is statistically significant $(\mathrm{p}=0.008)$. Similarly, there was an increase in political efficacy (0.1 to 0.4) as a result of the deliberation. This change is also statistically significant, but to a smaller degree $(\mathrm{p}=0.01)$. The results are summarized in Table 3 .

These results demonstrate that when properly set up, deliberations can achieve all three functions associated with deliberative democracy: participants can have the chance to express their opinions; there can be ample dialogue and communication, manifest in increased empathy, perspective-taking ability, and knowledge gains; and participants can come to a decision, however broad, together. Despite its limited size, this deliberation stands as a proof of concept regarding our ability to counteract the barriers that exist when deliberating on contentious topics such as accommodation of religious beliefs and practices.

\section{4}

\section{Conclusion}

Despite the backlash against the principles of multiculturalism in many Western democracies, the fact of multiculturalism - the presence of groups and individuals from different cultural and religious backgrounds-persists. Can 
deliberative democratic engagements relieve the tensions between diverse groups and increase cross-cultural and religious dialogue? This paper demonstrates that, when properly structured, this is possible, although it requires us to consider and remedy important barriers to deliberation.

The two cases described above are by no means perfectly comparable, but in the absence of a similar process of public debate in another province, the small deliberative engagement discussed in this paper represents the closest case available. ${ }^{72}$ Comparing these two conflict-fraught cases demonstrates that it is not the contentiousness of the topic of deliberation but rather the particular setup of the deliberation and its structure that determine the outcome. It is not that we cannot deliberate about religious and cultural differences and accommodation, but rather that we require these deliberations to be set up properly, so that we can counteract the barriers to deliberation caused by the contentiousness of these topics.

In the Sharia law debate, preexisting opinions and biases about Muslims in a post-9/11 world created undesirable conditions for an unregulated public deliberation. In particular, they led to structural inequality between the participants and a lack of representativeness of voices in the debate. For instance, newspaper coverage of the Sharia law debate was unequal. Of 113 people who were quoted by the three main newspapers (The Globe and Mail, the National Post, and the Toronto Star), 72 (64\%) were individuals who spoke against FBA and only $41(36 \%)$ who spoke in favor of it. ${ }^{73}$

As noted above, many voices were simply left out of the debate. Both these concerns are more easily remedied in a structured deliberation, with facilitators who can mediate the conversation. Such deliberation is better equipped to deal with biases that are liable to derail the conversation. Furthermore, careful recruitment and the presence of facilitators can ensure a degree

72 This is not to say that such deliberations have not taken place in British Columbia. West Coast LEAF (Women's Legal Education and Action Fund) held a workshop of "40 participants who included women from different communities of faith, community activists, lawyers and scholars in a Consultation on Women and Freedom of Religion" between December 2-5, 2004 (Jennifer Conkie, "A Reason to be Proud", 18(1) LEAFlet - The Newsletter of West Coast LEAF, Jan. 2005, 3). Although the BC Commercial Arbitration Act is often applied to family arbitration, in September 2004, BC Attorney General Geoff Plant announced that he did not plan on giving "any special recognition to any set of religious laws" (Karen Weiler, "Equality and the Family in Historical and Constitutional Perspective A Discussion", 4(13) Journal of Law and Equality (2005), 13, 16). This means that, in many ways, British Columbia has allowed a form of unregulated religious arbitration without going through the process seen in Ontario.

Korteweg, supra note 20, at 441. 
of equality between participants and the representativeness of the discourses in the deliberation. Within the larger public sphere, this requires reflection and remedies on the part of the print and visual media. Although it is beyond the scope of this paper to go into details about specific measures that need to be taken, a few suggestions are in order.

First, more needs to be done to "separate facts from opinion" and to focus on facts while "[treating] opinion as relevant." ${ }^{\text {" }}$ This is particularly important since the Sharia law debate demonstrated the ways in which mischaracterizations based on opinions seriously undermined the possibility of a meaningful public deliberation on the issue of religious arbitration. Second, to ensure the diversity of the news stories, more needs to be done to "invite members of religious and ethnic groups to come to the newsroom," and to "work with human resource departments to take into consideration newsroom diversity."75 Finally, there is a need to "organise training and workshops for journalists on issues related to tolerance, religion, security policy, rights of minorities, and reporting on vulnerable groups."76

Second, the Sharia law debate suffered from a general lack of information sharing between participants. It failed to inform the participants not only about the facts of the debate but also about the diversity of viewpoints. Part of this failure can be attributed to the increased polarization around the issue of $\mathrm{FBA}$, and to the way in which the media covered the issue. This barrier is more easily mitigated within mini-publics through the provision of information packages and inclusion of experts. In the larger public sphere, the onus is on the media to ensure free and accurate flow of information.

Finally, a core principle of deliberative democracy is that of consequentiality, the idea that "deliberative processes must have an impact on collective decisions or social outcomes." ${ }^{77}$ These consequences differ depending on the type of deliberative engagement. The decision by the McGuinty government not only violated this principle but also demonstrated the dangers of a public deliberation in which key stakeholders can make decisions that go against the recommendation of the deliberation in which they did not partake.

74 Verica Rupar, “Getting the Facts Right: Reporting Ethnicity and Religion”, Belgium: International Federation of Journalists (2012), 61.

75 Rupar, supra note 75 , at 62.

76 Ibid.

77 John S. Dryzek, "Democratization as Deliberative Capacity Building", 42(11) Comparative Political Studies (2009), 1379, 1382; Fung, supra note 4, 338-367; Goodin \& Dryzek, supra note 8 , at 219-244; Grönlund et al., supra note 4. 


\section{$5 \quad$ Appendix}

\subsection{Recruitment Procedures}

Participants were recruited using several methods:

1. An invitation at the end of the online survey as part of the larger project;

2. Invitation posters around campus;

3. Invitation email sent to students by different departments and electronic mailing lists;

4. Invitation email sent to student members of various clubs and organizations on campus;

5. Invitation posters in department newsletters;

6. Invitation posters in the social media sites/groups of various student clubs and organizations.

The last two methods of recruitment were used only when the researcher was asked to do so by departments or presidents of the clubs and organizations. Overall, 103 students expressed interest in participation. Sixty-one participants expressed secondary interest in the process, after more details were provided. Fifty-four confirmed their participation, and forty participants turned out for the deliberative engagements. Participants were paid $\$ 30$ and were reimbursed for additional costs.

The decision to rely on a student sample was made based on several considerations. One was ethical. The topic of the deliberative experiment requires participants to reflect on, present, and debate their cultural and religious values and practices. Debates over deeply-held values and interests, especially those that can challenge the ontological and emotional security of participants, can be uncomfortable. The logic behind using students was to reduce the risks associated with the study. Because participants deliberated with fellow students, there was a lesser degree of hierarchies between participants, which could have made some more vulnerable. Moreover, undergraduate and graduate students are more familiar with various research endeavors at the university than the general public is. They are often asked to participate in surveys and experiments conducted by fellow students, graduate students, or the faculty at the university. Finally, students are used to these kinds of discussions as part of their high school and university education, therefore their level of discomfort when engaging in deliberation should be minimal. Another reason had to do with financial constraints. The recruitment of participants from outside the university would have posed an undue financial burden on the investigator. 
5.2 Demographic Data of Participants

TABLE 4 Demographic data of participants

November $1(\mathrm{~N}=14) \quad$ November $7(\mathrm{~N}=16) \quad$ November $8(\mathrm{~N}=10)$

\section{Gender}

Female

Male

8

6

Transgender

o

$\begin{array}{rr}10 & 7 \\ 5 & 3 \\ 1 & 0\end{array}$

\section{Visible minority}

Yes

5

2

5

No

7

9

3

Don't know

2

5

2

\section{Ethnic background}

White

East Asian

5

South Asian

5

West Asian

0

Black

o

Latin American

1

Southeast Asian

2

Other

o

2

$\begin{array}{ll}8 & 4 \\ 4 & 4 \\ 2 & 1 \\ 2 & 0 \\ 0 & 1 \\ 0 & 0 \\ 1 & 0 \\ 2 & 0\end{array}$

\section{Religious attendance}

Frequently

Often

Moderately

Rarely

Never

$\begin{array}{lll}1 & 4 & 2 \\ 1 & 2 & 0 \\ 1 & 3 & 1 \\ 5 & 2 & 4 \\ 5 & 5 & 3\end{array}$




\subsection{Perspective-taking Index}

The composite variable perspective taking is made up of questions adopted from the Interpersonal Reactivity Index (Davis, 1983). The items are:

1. I try to look at everybody's side of a disagreement before I make a decision.

2. If I'm sure I'm right about something, I don't waste much time listening to other people's arguments.

3. When I'm upset with someone, I usually try to "put myself in his shoes" for a while.

4. Before criticizing somebody, I try to imagine how I would feel if I were in their place.

\subsection{Empathic Concern Index}

The composite variable empathic concern is made up of questions adopted from the Interpersonal Reactivity Index. The items are:

1. Sometimes I don't feel very sorry for other people when they are having problems.

2. Other people's misfortunes don't usually disturb me a great deal.

3. When I see someone being treated unfairly, I sometimes don't feel very much pity for them.

4. I'm often quite touched by things that I see happen.

5. I would describe myself as a pretty soft-hearted person.

\subsection{Knowledge Questions}

The composite variable knowledge includes the following items:

1. Arbitration is one of the legal methods available for dispute resolution in Canada.

2. British Columbia currently has/allows institutionalized religious arbitration.

3. The right to freedom of religion is one the arguments made against religious arbitration,

4. The right to equality under the law is one of the arguments made against religious arbitration.

5. The right to freedom of religion is one of the arguments made in favor of religious arbitration.

6. The right to free exercise of contracts is one the arguments made in favor of religious arbitration in British Columbia.

7. If we do not allow for institutionalized religious arbitration recognized by courts, people will not be able to use religious rules to resolve their disputes.

8. The Canadian Charter of Rights and Freedoms gives everyone a right to freedom of religion.

9. The Canadian Charter of Rights and Freedoms highlights multiculturalism as a value to be preserved and enhanced. 


\subsection{Descriptive Statistics of Variables}

TABLE 5 Descriptive statistics for two-point data variables

\begin{tabular}{llllll}
\hline & & Mean & N & Std. deviation & Std. error mean \\
\hline Knowledge & Pre & 0.53 & 40 & 0.29 & 0.05 \\
& Post & 0.65 & 40 & 0.24 & 0.04 \\
Perspective taking & Pre & 0.575 & 40 & 0.46 & 0.07 \\
& Post & 0.88 & 40 & 0.48 & 0.08 \\
Empathic concern & Pre & 0.84 & 40 & 0.65 & 0.1 \\
& Post & 0.95 & 40 & 0.68 & 0.11 \\
Decision-making & Pre & 0.6 & 40 & 0.71 & 0.11 \\
Politity & Post & 1 & 40 & 0.85 & 0.13 \\
& Pre & 0.1 & 40 & 1.17 & 0.19 \\
& Post & 0.4 & 40 & 1.19 & 0.19 \\
\hline
\end{tabular}

TABLE 6 Descriptive statistics for one-point data variables

Mean N Std. deviation

Others respected my views

Our group examined issues carefully

I had ample opportunity to talk

I learned as a result of deliberation

Deliberation helped me empathize with others

$\begin{array}{lll}1.62 & 40 & 0.49 \\ 1.45 & 40 & 0.55 \\ 1.48 & 40 & 0.68 \\ 1.25 & 40 & 0.78 \\ 1.08 & 40 & 0.62\end{array}$

\subsection{Data Sharing}

The deliberative experiments reported in this article were covered by Ethics Certificate number H13-0315 8 of June 12, 2014. In compliance with the ethics protocol, deliberation transcripts and identity of respondents cannot be made publicly available to ensure security and confidentiality of respondents. The survey analyses reported in this article were covered by the same Ethics Certificate. Data from pre- and postdeliberation questionnaires may be provided in the form of a STATA file, but in compliance with the ethics protocol, the IP addresses cannot be provided to ensure security and confidentiality of respondents. 


\section{Acknowledgments}

I would like to express my gratitude to Eric Schliesser, Laura Valentini, Christian List, Darrell Mollendorf, and Amy Hondo and anonymous reviewers for their constructive comments on the earlier drafts of this article. Any mistakes are my own. I want to thank Barbara Arneil, Mark Warren, and Fred Cutler whose help was instrumental in carrying out the larger research project. Finally, I wish to thank Justitia Amplificata, Goethe Universität Frankfurt, and Forschungskolleg Humanwissenschaften for their generosity, hospitality, and for providing an unparalleled academic atmosphere. This research was partly funded by the Social Sciences and Humanities Research Council of Canada. 